\title{
The Efficacy of MALL Instruction in Business English Learning
}

\author{
https://doi.org/10.3991/ijim.v13i08.9562 \\ Raja Muhammad Ishtiaq Khan $(\bowtie)$ \\ Majma'ah University, Zulfi, Kingdom of Saudi Arabia \\ r.khan@mu.edu.sa \\ Noor Raha Mohd Radzuan \\ Universiti Malaysia Pahang, Kuantan, Pahang, Malaysia. \\ Abdulmohsin Suliman Alkhunaizan, Ghulam Mustafa, Imran Khan \\ Majma'ah University, Zulfi, Kingdom of Saudi Arabia
}

\begin{abstract}
The existing technological expansion has transformed pervasive revolutions in modern civilization, with continuing innovation of services and products. Nowadays people are having different channels of communication. Currently, mobile learning (M-learning) is being used extensively in teaching and learning foreign languages which further widens the mobility of learners. The usage of mobile instruction can lead learners towards a real interruption to learn effectively when used inappositely. The current study is an attempt to explore the potential usage of M-Learning in English for specific purpose (ESP) classes. For this intention smartphones were used in the ESP context for teaching Business English at College of Business Administration at a public sector university in Saudi Arabia. A questionnaire was distributed to 21 participants of the present study after 5 week exposure to M-learning activities in formal classroom. The findings revealed that ESP learners acknowledge M-learning as a prompt source of feedback in ESP. The results of this study also indicate that incorporation of M-learning in ESP learning with conventional classroom can support learners to develop their learning proficiency. Moreover, learners showed significantly positive attitude in mobile instruction in formal classroom.
\end{abstract}

Keywords-M-Learning; ESP; Mobile instruction, MALL Technology

\section{Introduction}

\subsection{Background}

The use of technology is practicable from global world to formal classrooms and it has combined education with the need of learners to a great extent. Successful language instruction requires the enthusiasm and creativity to motivate learners as well as to keep the teaching alive in language classrooms (Beatty, 2013; Patel \& Jain, 2008; Pinter, 2017). The use of optimal instructional technology is a part of the provision of suitable 
learning environment and opportunities to connect the requirements and principles of language learning. Therefore, it is the basic requirement for EFL teachers to get required awareness of technology usage that will develop and foster learning effectively (Yang \& Chen, 2007). The moderate use of technology is fundamental aspect of inculcating technology as learners will face problems to grasp the positive usage of technology particularly in language classrooms. Moreover, right choice of technology is also mandatory for the achievement of desired goals as simple integration of technology cannot promise the learning enhancement in formal or informal classroom (Vrasidas \& Glass, 2005).

Learners acquire language informally by the means of availability of recourses. With the instant growth and persistent availability of digital handheld and mobile devices, technology has widened the access to learning material, which offers various learning expansion since early 1990s (Littlejohn \& Pegler, 2007; Warschauer, 2004). These readily available opportunities have vivid capacity to transform the mechanism of learning and in favor of this informal instruction can be easily initiated to impede the process of learning in conventional classrooms. Macfarlane and Ottewill (2013) asserted that these technology oriented openings can also expedite more shared and interactive learning environment for learners, which are radically distinctive from conventional and informal learning setting that includes the traditional methods of watching television and reading newspapers. The use of technology is beneficial when it is used for the development of academic goals of the syllabus and classroom activities instead of devising instruction for the better usage of technology and its skills. Similarly, the integration of technology in language classes also requires the careful planning to address the learners' needs and usability for language learning tasks. This assertion is also confirmed by the Levy and Stockwell (2013) as computers are meant to perform the role of teacher, tutor and tool conveniently. This sort of formal learning is typically directed by an instructor, while informal learning is predominantly learner-centered and self-directed (Ehlers, 2009; Hirumi, 2002; Marsick \& Watkins, 2015). As a result of the growing attraction of smartphones, digital technologies and the division between formal and in formal learning environment, is considered as immaterial (Bradwell, 2010).

Currently, android and smartphone technologies, as a platform for information and communication, have got a significant boost in the field of education recently and attracted the attention of various institutions to use it as instructional technology. This enormous familiarity has been guided by the development and availability of fast speed Wi-Fi, working habits, transformation of lifestyles and community standards (Salz \& Moranz, 2013). Hutchins (2014) also highlighted this fact that the expansion of internet is growing by the usage of personal computers and smartphones in different educational and normal life settings. Likewise, the rise of the usage of mobile learning in education in Saudi Arabia is also accelerated in recent years (Alsuwayed, 2017). However, the expansion of smartphone devices has been mirrored in numerous countries around the globe, principally due to its manifold function. So, there is increase in smartphone technologies for the experts in the field of education to adventure the digital transformation which includes the practicality of expanding the use of technology and android 
applications as a supplement to foster the language acquisition and learning sequence (Armstrong, 2016; Dingli \& Seychell, 2015; Penny, 2017).

\section{$1.2 \quad$ Research Questions}

The present attempt tries to explore the answers of the following questions:

1. Do ESP learners reflect the mobile phone integration as an efficient way to learning English for Specific Purposes?

2. Do ESP learners recognize mobile phones as a useful technology in learning language?

3. What sort of language learning activities do learners employ in on their mobile phones?

\section{Literature Review}

\subsection{Mobile Learning}

Broadly speaking, mobile learning includes any sort of leaning intervened by the means of using mobile phone devices (Wishart, 2017) which can happen anytime, anywhere and at suitability of the user. The viability of smartphones urged scholars, teachers, practitioners and researchers to turn the focus of their consideration to emergent technologies and their probability as language teaching instrument. Several attempts have been made to explain the term M-learning, and mostly it is referred and dedicated either on intervening technology or on learners' flexibility. Page (2014) refers mobile learning as an indication of the prospective development in learning other researchers regarded it as closely associated to M-learning as subset of E-learning (Anderson, 2008; Motiwalla, 2007). Park and Heidemann (2011) refer mobile learning on the usage of mobile phone devices or wireless devices for perseverance of learning at any place.

The arena of mobile learning is persistently developing and equally current and past studies attempt to explicate the characteristics and elements of mobile learning. The main focus of major researchers (Guy, 2010; Melhuish \& Falloon, 2010; Stockwell, 2007, 2010a; Stockwell \& Liu, 2015; Wan, 2013) was to develop consensual interpretation, pedagogy and framework that can be appropriately integrated in the shift of latest technologies, distinctive prospects and mobility of learners in formal and informal education framework. Therefore, sufficient understanding of the term of M-learning is essential for the best use of this technology. The most prominent mobile devices comprise of android smartphones, laptops, tablets, MP3 players and small portable PCs, all of these have capability to facilitate and develop the process of learning (Pereira \& Rodrigues, 2013). Contemporary expansions of social networking and social software have given smartphone devices more ubiquitous than in previous times, particularly it is more common amongst youth. M-learning software application should be guided by the instructors, irrespective of hurdles because of global change in the usage of software to attain its full benefits. The process of learning can occur well when it is aided by the 
usage of smartphone, that may be one of the key benefits of the learning (Zhang, Wei, \& Burston, 2011). In a meta-analysis Chee, Yahaya, Ibrahim, and Hasan (2017) also found a profound progression in developing learning skills of leaners. Most researchers (Al-Asmari \& Rabb Khan, 2014; Badwelan, Drew, \& Bahaddad, 2016; Fida, Farouq, Alamawi, \& Kamfar, 2017) also acknowledge M-learning as positive instrument in developing learning process in Saudi Arabia.

\subsection{Technology Integration in ESP Education}

The global business setting is currently controlled by the practice of English related to business, which subsequently is heading to a growing involvement about teaching English for specific purposes. The existing technological advancement has determined profound variations in society in the shape of availability of new inventions and facilities, and new modes of communications universally (Stehr \& Ruser, 2017). The prevalent usage of smartphone devices nowadays also provided appreciated place for teaching business English learners who have ample access of mobile devices, as it offers them supple and easy way to study their own. Because of the viability and availability of potable software and mobile phone devices is currently expanding and way there is also drastic change in teaching methodologies (Hadland, Borges-Rey, \& Cameron, 2017). M-learning offers learners the possibility of exceling the restricted atmosphere of conventional classroom to create an attractive learning self-sufficiency. So, this wide range of business English applications for the development of learners' ability has also advanced in recent years.

The association between information and communication technology and ESP stays well in a strong effect of Computer-assisted language learning (CALL) with the advancement in linguistics and language learning (Shih, 2010). Technology integration in ESP classes can be seen in the shape of various digital and smart tools, access to the high speed internet to engage the leaners in developing their understanding. Like other modes of language learning ESP also requires learner-centered apps for the experience of technology with conventional classroom teaching to make teaching atmosphere interested. The role of technology in ESP is to support the learners to access to reliable material that has been utilized as an additional help for learning purposes (NekrasovaBeker \& Becker, 2017). It has also further developed the ways of organizing related language task from outside of the classroom to the traditional classroom setting by persistent use of WhatsApp, Snapshot and many other smartphone applications. Therefore, integration of technology advances the visualization process of language learning effectively, when it comes to ESP context, it can be used as for the content and development of business related vocabulary. The usage of technology in ESP teaching has modernized the methods and material for ESP students (Bloch, 2013).

Researchers (Alemi, Sarab, \& Lari, 2012; Tayan, 2017) have indicated that learning backgrounds which are associated with enhancement of technological motivation for the learners, are more beneficial as compared to other methods of language instruction. McDonough and McDonough (2014) proposed that ESP requires a different approach and activities and it has also separate schema in the field of applied linguistics platform. Moreover, it has its own teaching methodologies and ways of engaging learners as well 
as its interdisciplinary in research. Thus, it is a great delusion that findings of technological integration in EFL context can also be generalized to the finding of ESP teaching. In rapid revolutionizing instructive education environment, the potentials of technological learning are developing and they can be replaced to obsolete traditions of learning environment.

The result of Falloon (2017) identified the importance of the associating MALL with traditional classrooms. The function of handheld devices and scaffolding helped learners' to construct their understanding and link their experiences positively. Similarly, the use of MALL approach result in developing self-determined techniques outside the conventional classroom boundaries, where virtual connections and mobile phone devices bump into developing the goal of target language conversation requirements and benefits (Kukulska-Hulme, Lee, \& Norris, 2017). The current attempt is also a part of modern technology to understand the process and need of integrating MALL technology in Arabic speaking ESP learners of accounting section of a public university of KSA.

\section{$3 \quad$ Methodology and procedure}

\subsection{Methodology}

The present study used the quantitative method for collecting data. Quantitative method allows researchers to be more reliable and objective in the results (Brannen, 2017). In order to quantify the results a questionnaire was adopted after analyzing previous studies in the filed relating MALL studies. The use of questionnaire is a useful and operative way of collecting data and information on the perceptions and attitudes of study participant on a given field or subject matter (Brown, 2001). All the learners were given 15 minutes after the formal classroom to engage in MALL activities. Learners were allowed to use their smartphones freely for the discussion about the taught topic. Learners were exposed to use their smartphones in the last part of their class for five weeks. For this purpose a WhatsApp group was created by the researcher and all the learners were asked to practice their exercises in this group. They shared their classroom activities by using WhatsApp. The data was collected in first academic semester of 2017.

\subsection{Participants and Instrument of the study}

21 ESP learners from College of Business Administration of a public university of Saudi Arabia participated in this research study. They study ESP as part of their syllabus for a period of one semester. All of the learners were assumed to have a similar level of English as they were placed in groups after a university placement test at the time of registration. The first language of learners is Arabic and they use Arabic as means of communication in campus. All of the learners have smartphones with fast data connection but they didn't have any past experience of using smartphones as an aid in 
learning in the classroom. However, for current study they were exposed to use their cellphones during their classes regularly for a course of one semester.

Quantitative method was employed to gather the related information for the current study. The researcher inspected different prominent specialists in order to adopt questionnaire for collecting data. Moreover, the selection of classroom activities was also analyzed to check the recognition for the need of mobile learning in ESP classes. A questionnaire was adapted mainly from two different previous studies (Gaudreau, Miranda, \& Gareau, 2014; Palalas, 2011). In the first part, seven elements on the usage of effectiveness were chosen to gauge the learners' understanding of-learning. Learners were asked to respond to these elements on the 5 point Likert scale from strongly disagree to strongly agree about the instruction of M-learning for ESP classes. The second section of questionnaire was related to learners' usage of M-Learning in conventional classroom setting. This part consisted of six elements where learners had to mark their understanding on the basis of 5 point Likert scale from never to very often frequency. In the last part of the questionnaire, advantages and disadvantages of mobile-based instruction in classroom were analyzed. Learners had to choose from already selected advantages and disadvantages from Palalas (2011).

\section{$4 \quad$ Data collection and Results}

After five weeks of the exposure of using smartphone, learners were asked to complete the questionnaire. They were asked to complete the questionnaire in their class time. The questionnaire was administered to preform intact group of 21 students of College of Business Administration faculty. After getting responses from the learners, data was evaluated descriptively by coding means and the percentages of the replies from the students. The remarks were separately collected and calculated in the final outcomes, therefore covering more individual awareness and learners' perception on the use of mobile phones in ESP classes. Moreover, data were also collected and analyzed descriptively on the prelisted advantages and disadvantages of smartphone integration in formal ESP classes.

\subsection{The use of Smartphones in ESP classes}

All the students were inquired to appraise their usage of smartphones after 5 weeks of smartphone instructions during conventional classroom on Likert scale from 1 to 5 (Very often $=5$; often $=4$; rarely $=3$; very rarely $=2$ and never; 1 ). Table 1 explains the usage of smartphone usage in typical classroom as an aid to their formal classes. 
Table 1. The use of Smartphones in ESP classes

\begin{tabular}{|l|c|c|c|c|c|}
\hline \multicolumn{7}{|c|}{ The use of smartphones in ESP Classes } \\
\hline & Never & Very Rarely & Rarely & Often & Very often \\
\hline Searching supplementary material using Mobile & 0 & $25 \%$ & $35 \%$ & $40 \%$ & 0 \\
\hline Sending emails using Mobile & 0 & $59 \%$ & $51 \%$ & 0 & 0 \\
\hline Navigating Educational websites & 0 & $14 \%$ & $67 \%$ & $19 \%$ & 0 \\
\hline Note taking on the phone in the class & 0 & $17 \%$ & $43 \%$ & $40 \%$ & 0 \\
\hline Use of social media & 0 & $17 \%$ & $43 \%$ & $40 \%$ & 0 \\
\hline Use of phone for taking pictures & $9 \%$ & $55 \%$ & $27 \%$ & $9 \%$ & \\
\hline
\end{tabular}

Adapted from (Gaudreau et al., 2014).

This is obvious form the results that highest numbers of the learners were engaged in browsing internet to look for the supplementary material related to their formal classroom instructions and sending emails by the means of using smartphones. It is obvious from the above results that $59 \%$ students used smartphone for sending emails and $40 \%$ of students employed their efforts in finding supplementary material in classroom. Moreover, highest percentage of students indicated that they rarely used their smartphones for the searching class-related material as compared to $19 \%$ who used smartphones for this purpose. However, it is also noteworthy that a considerable number of students utilized their smartphones in browsing social network page in the class. The purpose of using smartphones for social networking can be further investigated. The minimum percentage was noticed for taking pictures during their classroom.

Effectiveness of Mobile Instruction in ESP Classes. To evaluate the efficiency of learners' development after using smartphones during the class time, learners were asked to gauge the effectiveness of smartphone instructions. They had to evaluate smartphone instructions on the identical scale ranging from 1-5 (Strongly Agree $=5$; Agree $=4$; No opinion $=3$ : Disagree $=2$; strongly disagree $=1$ ). The table listed below explains the responses of ESP learners. The items of this part of questionnaire were adapted (Palalas, 2011).

Table 2. Mobile Instruction in ESP classes

\begin{tabular}{|l|c|c|c|c|c|}
\hline \multicolumn{7}{|c|}{ MALL Instruction in ESP classes } \\
\hline & $\begin{array}{c}\text { Strongly } \\
\text { Agree }\end{array}$ & Agree & Neutral & Disagree & $\begin{array}{c}\text { Strongly } \\
\text { Disagree }\end{array}$ \\
\hline $\begin{array}{l}\text { MALL offered an effective way of learning } \\
\text { language }\end{array}$ & $12 \%$ & $67 \%$ & $19 \%$ & $2 \%$ & 0 \\
\hline Developed English Learning Proficiency & $3 \%$ & $87 \%$ & $10 \%$ & 0 & 0 \\
\hline MALL offered Learners' centered learning & $18 \%$ & $52 \%$ & $17 \%$ & $10 \%$ & $3 \%$ \\
\hline $\begin{array}{l}\text { MALL provided and easy and fun way of } \\
\text { learning }\end{array}$ & $11 \%$ & $69 \%$ & $8 \%$ & $12 \%$ & 0 \\
\hline I learned better with smartphone & $2 \%$ & $34 \%$ & $28 \%$ & $36 \%$ & 0 \\
\hline I would use different apps for learning English & $87 \%$ & $9 \%$ & $4 \%$ & 0 & 0 \\
\hline Smartphones are a distraction in class & 0 & $13 \%$ & $10 \%$ & $59 \%$ & $28 \%$ \\
\hline
\end{tabular}

Adapted from (Palalas, 2011). 
Students' responses indicate that M-learning is most operative part of learning. The data presents vital indication of improvement of learners' proficiency in learning English. $87 \%$ learners approved the instruction of smartphones develop learners' proficiency effectively. Moreover, a considerable numbers of leaners also agreed that mobile learning is an easy and enjoyable method of ESP learning. Similarly, 87\% leaners also should their inclination towards the usage of smartphones applications for self-directed learning for ESP classes. However, some learners also identified that smartphone may cause distraction in classes but this percentage languished below the considerable number. Some learners showed indifference in integrating smartphone software in ESP classes. Nevertheless, many learners have marked smartphone integration as a fun way of learning.

\subsection{Advantages and disadvantages of smartphone instruction in ESP Classes}

Students were asked to mark prelisted advantages and disadvantages of smartphone immersion in formal classes that apply to their situation in the last section of the questionnaire. They were allowed to choose as many as they think comply with their situation in formal classroom teaching. The responses of students are listed below:

Table 3. Advantages of Smartphones Instruction in ESP classes.

\begin{tabular}{|l|l|}
\hline \multicolumn{2}{|c|}{ Usefulness of smartphones instruction in ESP Classes } \\
\hline Learning Material is readily available & $73 \%$ \\
\hline Ubiquitous Learning & $52 \%$ \\
\hline Pronunciation development & $28 \%$ \\
\hline Fun way of Learning & $39 \%$ \\
\hline Source of instant Feedback from instructor & $88 \%$ \\
\hline Offers collaborative learning & $41 \%$ \\
\hline
\end{tabular}

Table 4. Disadvantages of smartphones Instruction in ESP classes.

\begin{tabular}{|l|c|}
\hline \multicolumn{2}{|c|}{ Disadvantages of smartphones instruction in ESP Classes } \\
\hline Small screen size & $58 \%$ \\
\hline Data connectivity & $89 \%$ \\
\hline Material surfing is time consuming & $20 \%$ \\
\hline Lack of interactivity & $30 \%$ \\
\hline Technical problems & $40 \%$ \\
\hline
\end{tabular}

This is viable from the responses collected from students, the immediate and instantaneous availability of accessible data; prompt feedback from peers or instructors are undoubtedly the prime advantages of smartphones instruction in formal ESP classes for the development of learning process. Most of the students indicated it a beneficial method of getting required information or details of certain responses whenever they need to look for online material. Furthermore, receiving and delivering instant comments is also regarded to be specifically helpful and productive way. Similarly, several 
students from the targeted group also contemplate it as collaborative learning in the possibility to get required aid when required and less numbers of students regard smartphone instruction as fun way of learning in class. Contrarily, students also indicated smartphone instruction as problematic in learning process because of the lack of free access to Wi-Fi or data in the class. A remarkable number of students marked battery that glitches in using their smartphone for effectiveness of ESP instruction in the classroom. Some students also labeled the typing problem on small screen and duration of time for downloading material as it may create lack of connectivity and interaction is ESP learner exposure. However, it is noteworthy that time consumption percentage is languished at $20 \%$ which is important factor in formal classroom because of the time constraint of schedule.

\section{Conclusion}

No one can deny the fact of the ubiquitous presence of smartphones in our surroundings as chief source of communication in particular and an effective teaching aid for the progression of educational methods in general. The present study was an attempt to measure the potential of the M-learning integration in ESP context. The results of this study are in line with previous MALL studies (Badwelan et al., 2016; Macfarlane \& Ottewill, 2013; Stockwell, 2010b) by creating different diverse learning opportunities. Due to its ubiquitous presence, this technology has a great role in language learning and teaching process. Owing a smartphone allows individuals to associate and develop coordination without any time constraint. Neglecting this proficiency of smartphones, in fact, is refusal of adopting modern methodologies. Like EFL teaching, ESP teaching also demands the attention of teachers to boost the possibility of mobile phones integration to get the benefit of this hand-held device. Therefore, the target of ESP teachers should be maximizing the utility of smartphones in typical and informal teaching situations. The goal of using technology should be the development of teaching process; not the usage of smartphones but in the way as these gadgets can assist learning accordingly. The findings of the data of present attempt indicated that usage of technology in ESP classroom need careful handling and management of this approach.

The integration of smartphones in this study fostered the process of provision of feedback effectively in ESP classes. A language instructor or a teacher can monitor the group activities as well as he can trace the performance of learners easily even if the number exceeds than the set standards. Similarly, it is an effective way of finding a solution of encountered problem by learners themselves. The result is self-directed learning and development of confidence among themselves. Moreover, from learners' perspective, smartphones are useful source of inducing constructivist -based background that can also affect the motivational level, collaboration and individualized engagement in learning process. Furthermore, the results of this study also indicate that integration of M-learning in ESP learning in traditional classroom can assist learners to develop their learning proficiency. In addition to the persistent benefits of M-learning, it is also important to consider the effective and purposeful usage in classroom. If the M-learning activities are not planned carefully, this technology can be real distraction 
and mere wastage of time. So, careful handling and planning for developing learning process is essential part of devising M-learning classroom environment.

\section{Implications and Limitation of the Study}

It is commonly known fact the MALL is now indispensable learning asset and previous studies had established its positive effect on English language learners impressively. The present study suggests some implications of M-learning implementation and providing applied advantages of this learning tool efficiently. Firstly, it is valuable to integrate such learning tools in ESP language teaching by using already developed technological soft-wares programs to facilitate learners with attractive and motivating learning system inside as well as outside of the formal classroom setting. Moreover, curriculum developers and ESP instructors need to encourage learners to use this technology purposefully and for the sake of progression of their language learning. In addition the incorporation of this useful technological tool by the instructors provides opportunity of self-directed learning to great extent and learners' language learning efficiency can be developed by the means of interaction and communication with peers and instructors. The result is scaffolding effect on the ESP learners' learning ability. This enables leaners to share, discuss, correct, expand and assign responsibilities during the course of communication with teachers (Boettcher \& Conrad, 2016).

Additionally, MALL is newly developed approach in teaching and learning process in education particularly in second or foreign language learning. Principally it signifies the practice of hand-held smartphone devices and tablets to learn and advance their language learning skills both in EFL and ESP context effectively. Literature is abundant with the studies that have been carried out in the recent past globally as well as in Saudi Arabia (Al-Asmari \& Rabb Khan, 2014; Al-Masrai \& Milton, 2012). In addition to numerous advantages, it also facilitates learners to be independent in learning process at the ease of the utility of time and background.

Like other research investigations, this study has also some limitations. The current study is limited to one section of a public university in ESP learning field with limited number of participants. Therefore, the findings of this attempt cannot be generalized to the other aspects of ESP learning as different subject matter requires different methodology. Moreover, if the study includes large number of students, more profound understanding of M-learning can be attained precisely. In addition, if the mobile instructions for classroom usage are given to participants better results can be gathered. Irrespective of less number of participants and M-learning usage in formal class current attempt is a solid foundation for further experimental research in this arena.

\section{$7 \quad$ References}

[1] Al-Asmari, A. M., \& Rabb Khan, M. S. (2014). E-learning in Saudi Arabia: Past, present and future. Near and Middle Eastern Journal of Research in Education, 2. https://doi.org/10 $.5339 /$ nmejre.2014.2 
[2] Al-Masrai, A., \& Milton, J. (2012). The Vocabulary Knowledge of University Students in Saudi Arabia. TESOL Arabia Perspectives, 19(3), 13-19.

[3] Alemi, M., Sarab, M. R. A., \& Lari, Z. (2012). Successful learning of academic word list via MALL: Mobile Assisted Language Learning. International Education Studies, 5(6), $99-$ 109. https://doi.org/10.5539/ies.v5n6p99

[4] Alsuwayed, H. (2017). Cloud-based E-learning Systems in Saudi Universities. Auckland University of Technology.

[5] Anderson, T. (2008). The theory and practice of online learning: Athabasca University Press.

[6] Armstrong, T. (2016). The power of the adolescent brain: Strategies for teaching Middle and High School students: ASCD.

[7] Badwelan, A., Drew, S., \& Bahaddad, A. A. (2016). Towards Acceptance M-Learning Approach in Higher Education in Saudi Arabia. International Journal of Business and Management, 11(8), 12. https://doi.org/10.5539/ijbm.v11n8p12

[8] Beatty, K. (2013). Teaching \& Researching: Computer-Assisted Language Learning: Routledge.

[9] Bloch, J. (2013). Technology and ESP. The handbook of English for specific purposes, 385401.

[10] Boettcher, J. V., \& Conrad, R.-M. (2016). The online teaching survival guide: Simple and practical pedagogical tips: John Wiley \& Sons.

[11] Bradwell, P. (2010). The edgeless university: Why higher education must embrace technology.

[12] Brannen, J. (2017). Mixing methods: Qualitative and quantitative research: Routledge.

[13] Brown, J. D. (2001). Using surveys in language programs: Cambridge University Press.

[14] Chee, K. N., Yahaya, N., Ibrahim, N. H., \& Hasan, M. N. (2017). Review of mobile learning trends 2010-2015: a meta-analysis. Journal of Educational Technology \& Society, 20(2), 113-126.

[15] Dingli, A., \& Seychell, D. (2015). The new digital natives: Cutting the chord: Springer.

[16] Ehlers, U. D. (2009). Web 2.0-e-learning 2.0-quality 2.0? Quality for new learning cultures. Quality Assurance in Education, 17(3), 296-314. https://doi.org/10.1108/09684880 910970687

[17] Falloon, G. (2017). Mobile devices and apps as scaffolds to science learning in the primary classroom. Journal of Science Education and Technology, 26(6), 613-628. https://doi.org/ 10.1007/s10956-017-9702-4

[18] Fida, N. M., Farouq, M., Alamawi, D., \& Kamfar, H. (2017). Undergraduate medical students' perceptions of their learning experience in pediatric rotation at King Abdulaziz University Medical College in Jeddah, Saudi Arabia. Medical Teacher, 39(sup1), S37-S44. https://doi.org/10.1080/0142159x.2016.1254747

[19] Gaudreau, P., Miranda, D., \& Gareau, A. (2014). Canadian university students in wireless classrooms: What do they do on their laptops and does it really matter? Computers \& education, 70, 245-255. https://doi.org/10.1016/j.compedu.2013.08.019

[20] Guy, R. (2010). Mobile learning: Pilot projects and initiatives: Informing Science.

[21] Hadland, A., Borges-Rey, E., \& Cameron, J. (2017). Mobile phones and the news: How UK mainstream news broadcasting is stalling the video revolution. Convergence, 1354856517703964.

[22] Hirumi, A. (2002). Student-centered, technology-rich learning environments (SCenTRLE): Operationalizing constructivist approaches to teaching and learning. Journal of Technology and Teacher Education, 10(4), 497-537. 
[23] Hutchins, B. (2014). Sport on the move: The unfolding impact of mobile communications on the media sport content economy. Journal of Sport and Social Issues, 38(6), 509-527. https://doi.org/10.1177/0193723512458933

[24] Kukulska-Hulme, A., Lee, H., \& Norris, L. (2017). 15 Mobile Learning Revolution: Implications for Language Pedagogy. The Handbook of Technology and Second Language Teaching and Learning, 217. https://doi.org/10.1002/9781118914069.ch15

[25] Levy, M., \& Stockwell, G. (2013). CALL dimensions: Options and issues in computer-assisted language learning: Routledge.

[26] Littlejohn, A., \& Pegler, C. (2007). Preparing for blended e-learning: Routledge.

[27] Macfarlane, B., \& Ottewill, R. (2013). Effective learning and teaching in business and management: Routledge.

[28] Marsick, V. J., \& Watkins, K. (2015). Informal and Incidental Learning in the Workplace (Routledge Revivals): Routledge. https://doi.org/10.4324/9781315715926

[29] McDonough, J., \& McDonough, S. (2014). Research methods for English language teachers: Routledge.

[30] Melhuish, K., \& Falloon, G. (2010). Looking to the future: M-learning with the iPad.

[31] Motiwalla, L. F. (2007). Mobile learning: A framework and evaluation. Computers \& education, 49(3), 581-596.

[32] Nekrasova-Beker, T., \& Becker, A. (2017). 6 Integrating Project-Based Learning into English for Specific-Purposes Classrooms. Language for Specific Purposes: Trends in Curriculum Development, 101.

[33] Page, T. (2014). Application-based mobile devices in design education. International Journal of Mobile Learning and Organisation, 8(2), 96-111. https://doi.org/10.1504/ijmlo.2014. 062347

[34] Palalas, A. (2011). Mobile-assisted language learning: Designing for your students. Second language teaching and learning with technology: views of emergent researchers, 71-94. https://doi.org/10.14705/rpnet.2011.000007

[35] Park, U., \& Heidemann, J. (2011). Data muling with mobile phones for sensornets. Paper presented at the Proceedings of the 9th ACM Conference on Embedded Networked Sensor Systems. https://doi.org/10.1145/2070942.2070960

[36] Patel, M., \& Jain, P. M. (2008). English language teaching: Sunrise Publishers and Distributors.

[37] Penny, J. (2017). Learning Rebooted: Education Fit for the Digital Age: Routledge.

[38] Pereira, O. R., \& Rodrigues, J. J. (2013). Survey and analysis of current mobile learning applications and technologies. ACM Computing Surveys (CSUR), 46(2), 27. https://doi. org/10.1145/2543581.2543594

[39] Pinter, A. (2017). Teaching young language learners: Oxford University Press.

[40] Salz, P. A., \& Moranz, J. (2013). The everything guide to mobile apps: A practical guide to affordable mobile app development for your business: Everything Books.

[41] Shih, R.-C. (2010). Blended learning using video-based blogs: Public speaking for English as a second language students. Australasian Journal of Educational Technology, 26(6). https://doi.org/10.14742/ajet.1048

[42] Stehr, N., \& Ruser, A. (2017). Knowledge Society, Knowledge Economy and Knowledge Democracy. Handbook of Cyber-Development, Cyber-Democracy, and Cyber-Defense, 120. https://doi.org/10.1007/978-3-319-06091-0_16-1

[43] Stockwell, G. (2007). Vocabulary on the move: Investigating an intelligent mobile phonebased vocabulary tutor. Computer Assisted Language Learning, 20(4), 365-383. https:// doi.org/10.1080/09588220701745817 
[44] Stockwell, G. (2010a). Using mobile phones for vocabulary activities: Examining the effect of platform.

[45] Stockwell, G. (2010b). Using mobile phones for vocabulary activities: Examining the effect of the platform. Language Learning \& Technology, 14(2), 95-110.

[46] Stockwell, G., \& Liu, Y. C. (2015). Engaging in mobile phone-based activities for learning vocabulary: An investigation in Japan and Taiwan. Calico Journal, 32(2), 299. https:// doi.org/10.1558/cj.v32i2.25000

[47] Tayan, B. M. (2017). Students and Teachers' Perceptions into the Viability of Mobile Technology Implementation to Support Language Learning for First Year Business Students in a Middle Eastern University. International Journal of Education and Literacy Studies, 5(2), 74-83. https://doi.org/10.7575/aiac.ijels.v.5n.2p.74

[48] Vrasidas, C., \& Glass, G. V. (2005). Achieving technology integration in classroom teaching. Preparing teachers to teach with technology, 3, 1-20.

[49] Wan. (2013). Conceptualising mLearning literacy. International Journal of Mobile and Blended Learning (IJMBL), 5(1), 1-20.

[50] Warschauer, M. (2004). Technology and social inclusion: Rethinking the digital divide: MIT press.

[51] Wishart, J. (2017). Mobile Learning in Schools: Key Issues, Opportunities and Ideas for Practice: Routledge. https://doi.org/10.4324/9781315536774

[52] Yang, S. C., \& Chen, Y.-J. (2007). Technology-enhanced language learning: A case study. Computers in Human Behavior, 23(1), 860-879.

[53] Zhang, H., Wei, S., \& Burston, J. (2011). Reexamining the effectiveness of vocabulary learning via mobile phones. TOJET: The Turkish Online Journal of Educational Technology, 10(3).

\section{Authors}

Raja Muhammad Ishtiaq Khan is an English language Lecturer at Al-Majma'ah University, Saudi Arabia. He has a Cambridge CELTA certificate in teaching and has 10 years of experience in ESL and EFL. He is a PhD scholar and his research interests include Applied Linguistics, MALL, L2 Vocabulary learning and Teaching, Second Language Acquisition and EFL teaching (r.khan@mu.edu.sa).

Noor Raha Mohd Radzuan is a senior Lecturer at Univeristi Malaysia Pahang, Malaysia. She earned her PhD in Applied Linguistics from Universiti Sains Malysia, Malysia. She has more than 12 years working experience. Her research interest includes workplace communication, second language learning strategies, L2 vocabulary learning and students' motivation (nraha@ump.edu.my).

Abdulmohsin AlKhunaizan is currently serving as an assistant professor at Majmaah University in the department of Information Systems and Computer Science. $\mathrm{He}$ is also serving as a Dean of PYP program of Majmaah University. He holds a PhD in information system, Brunel University UK. His research interests include M-Commerce, E-Learning and Mobile social network use (a.alkhunaiza@mu.edu.sa).

Ghulam Mustafa is an English language Lecturer at Al-Majma'ah University, Saudi Arabia. He has a Cambridge CELTA certificate in teaching and has 15 years of experience in ESL and EFL. He holds PGD in ELT degree from University of the 
Punjab. He is a PhD scholar and his research interests include Applied Linguistics, Second Language Acquisition and EFL teaching (g.ismail@mu.edu.sa).

Imran Khan is an English language Lecturer at Al-Majma'ah University, Saudi Arabia. He holds a master degree in English Language \& Literature and has 19 years of experience in ESL and EFL. He is a PhD scholar and his research interests include Applied Linguistics, CALL, L2 Reading, Second Language Acquisition and EFL teaching (imkk2010@gmail.com).

Article submitted 2018-09-18. Resubmitted 2019-04-17. Final acceptance 2019-05-12. Final version published as submitted by the authors. 